\title{
Medical Sciences: Japan and the Netherlands
}

\author{
R.G.A. Ackerstaff, M.D., Ph.D. \\ St. Antonius Hospital, Nieuwegein (Utrecht), The Netherlands
}

\section{Introduction}

The first contacts of Japan with the West probably were with the Portuguese when in October 1543 a few Lusitanian sailors were shipwrecked in southwestern Japan. In these times, the Portuguese had made many important trade connections in India and along the coast of China. They settled in Goa and took possession of Macao. During the second half of the sixteenth century the Portuguese came yearly to the southern island of Kyushu for trade as well as Christian missions. In Japan, the feudal lords were still independent and made personal contracts with the Portuguese traders. Some of the lords received instruction in the Christian doctrine and became converted to Christianity. In their Christianizing program the Jesuits and later the Franciscans and Dominicans from Manilla were remarkably successful. However, in medicine the missionaries made little effort and, therefore, no lasting impact. During this period, Japan was brought to a close by the determination of a succession of Japanese military rulers to establish a completely feudal state. The military rulers felt that the Christian missionaries distracted their people to a degree that made such a development difficult. They were also concerned about the possibility of a rebellion by the Christian converts, possibly instigated and supported by the Portuguese or Spanish armies. Finally, the unification of Japan and the establishment of a feudal society was accomplished in 1600 by the great warlord Tokugawa Ieyasu. Although Tokugawa Ieyasu and his successors move steadily to close the country, they also wished to maintain an opening to the West. There only possible choice was the Dutch. In 1609 the Hollanders had established a trading post on Hirado Island near Kyushu. In contrast to the Iberians, their sole concern was for trade and they steadfastly disavowed any plans to establish Christian missions.

\section{The Hollanders on Deshima}

In 1598 a fleet was equipped in the harbour of Rotterdam, destined to go to the Moluccan Islands in Dutch East India. The fleet consisted of five ships: de Liefde, de Hoop, het Geloof, de Trouw, and de Blijde Boodschap. On board of the admirals ship an Englishman William Adams was first mate. The fleet sailed from Holland in 1598 and the journey was not very successful. The crew suffered from diseases which caused the deaths of many of them. The winter of 1598-1599 was spent in the Strait of Magellan. The ships hit raging storms in the Pacific, they were scattered and finally four of them foundered. During the trip Adams was transferred to the ship de Liefde and on 19 April 1600 this ship alone landed on the Japanese shore. After enduring a period of fourty days in which the crew members were imprisoned and condemned to death, Adams was granted several audiences to the court of the shogun. Ieyasu was deeply interested in many details about foreign countries and Adams managed to come into his good grace to such an extent that the shogun rewarded him for his services by giving him an imperial position with a very generous salary. In July 1609 a second mission sailed from Batavia to Hirado where they succeeded in being admitted to the court. Owing to the intercession of Adams they were very well received and on the 26 th of July 1609 Tokugawa Ieyasu gave the Dutch permission to trade under fairly profitable conditions (Fig .1). Although this permit was valid until 1856 when the first new treaty regulations were concluded with the Netherlands, the Dutch position in Japan became soon seriously undermined. The chief commissioner of the Dutch factory, Koeckebakker, became involved in a local combat against Japanese Christians which resulted in a terrible carnage and total eradication of all Christians. In 1638 the last Portuguese 


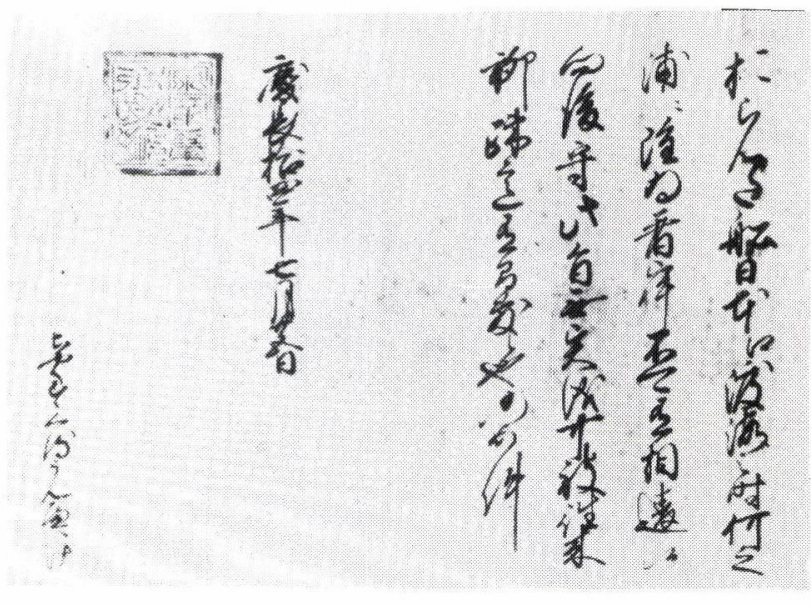

Fig. 1 A commercial document (trade paper) given to the Dutch by the shogun Tokugawa Ieyasu; dated $26^{\text {th }}$ July, 1609.

traders were expelled and three years later, 1641, the Hollanders were removed from Hirado to an artificial peninsula, Deshima, in Nagasaki bay. On this spot which is as large as the Dam in Amsterdam the Dutch had tolerated living like real prisoners for more then two centuries. They were strictly guarded and even prohibited from speaking to any well-educated Japanese beyond the call of duty. The only contact the Hollanders had with the outside world was with the summer monsoon when two ships from Batavia sailed to Nagasaki to trade with the Japanese. The bans against the exchange of information was buttressed by a serious language gap: the Dutch were not permitted to learn Japanese, and the Japanese knew no Dutch. Moreover, for the first half-century communication was in Portuguese, a language which the Dutch Protestants detested.

\section{Exchange of medical knowledge}

Mostly, about a dozen employes of the Dutch East India Company (VOC) lived on the tiny island in Nagasaki bay, together with the Indonesian servants they had brought. Life on Deshima had a very fixed pattern and an important event in the routine was the obligatory journey to the court of the shogun in Edo. Every year the chief commissioner (opperhoofd) had to inform the shogunate government on the lastest political news. However, there was also great interest in European achievements in the field of astronomy, geography, cartography, military

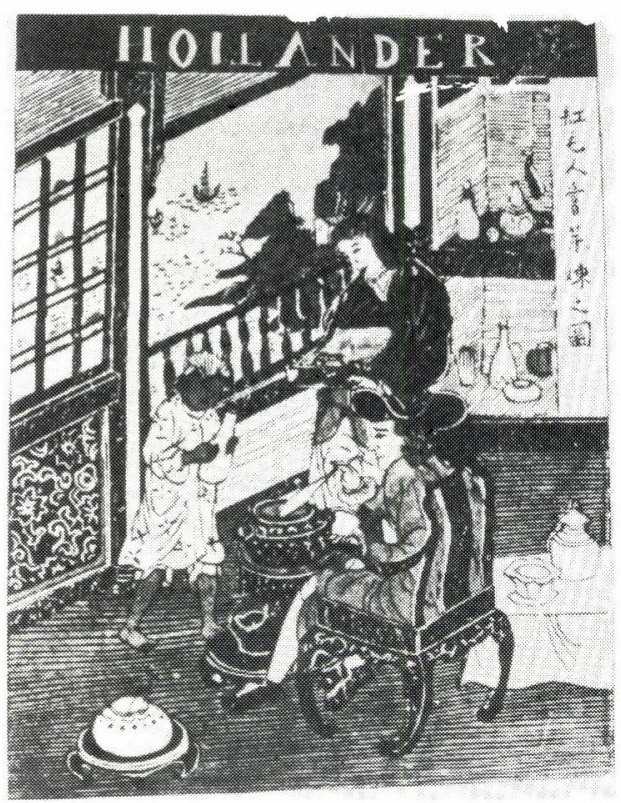

Fig. 2 A Dutch physicina perparing plaster of Paris for medical purposes, a woodcut from the first half of the $19^{\text {th }}$ century.

skills, botany, and medicine. In addition to the flow of Western knowledge into Japan, there was also a flow of knowlegde about Japan and its culture to Europe, usually through the writings and collections of the doctors.

Officially appointed interpreters were the only Japanese authorized by the shogunate government to learn Dutch and, therefore, the interpreters held a keyposition in the Dutch-Japanese relations. As most professions in Japan, that of the interpreter was heriditary. Among the VOC-employees the physicians held also a special position. Their profession gave them the opportunity to leave the island on more occasions and establish closer contacts with the Japanese than was possible for many other members of the VOC. Routinely one doctor served on Deshima, sometimes assisted by a botanist or pharmacist. Moreover, the Dutch community on Deshima was very small and not too demanding. From 1650 the shogunate government explicitely requested the participation of a physician to the visiting party to Edo. In the capital high-placed officials and their Japanese physicians used the European doctor to consult him on medical matters. At Deshima the VOC-doctors were likewise consulted by high-ranking Japanese officials like governers and commissioners (Fig .2). Some of the Japanese 
officials and interpreters became deeply interested in western medicine and natural history. They asked for books, medical instruments, herbs, and medicines. That the Japanese accepted western medicine did not mean that they rejected traditional Japanese medicine. Classical Japanese medical treatment was based on traditional Chinese medicine, which stressed the function of organs more than their place and structure. Particularly little was known about human anatomy, western surgery and obstetrics. Treatment was based mainly on acupuncture, moxibustion and message in combination with mostly herbal medicines. Among the interpreters who made the change to the medical profession were founders of what later became famous medical families as for example the Nishi, the Motoki, the Narabayashi, and the Yoshida. Some were appointed subsequently as a personal physician to the shogun. Nishi Kichibei Genpo (1636-1684) studied western medicine for a long time under several VOC-doctors. In 1668 Arnout Dirckz granted a medical certificate to Genpo who then changed to the medical profession. Such a certificate was much desired by the Japanese who had been taught western medicine. They then legitimately could call themselves "Oranda-ryugeka"(surgeon of the Dutch school of medicine) a title which gave them particular prestige. Sometimes, "Orandaryu-geka"received on their own request a Dutch name, as for example Pieter Gezond or Flip Genezen. Japanese scholars of western medicine also wrote down what they had learnt from the Dutch physicians in manuscripts and books, partly for their own ambition, partly because they were assigned to do it. Examples of such writings are "Oranda-geka-sho"(Dutch book of surgery) by Inomata Dembei and "Komo geka hiyo"(Secret elements of Dutch surgery). The latter had been published in 1657 by Mukai Gensho (1608-1677). Usually, these manuscripts or books were secret. The most probable explanation is that Japanese physicians who had qualified in Dutch medicine regarded themselves superior to colleagues who did not have such a qualification. Moreover, translation of western books was not without risk. After 1630 various edicts had been issued by the shogunate government to ban western books. The most important event in the introduction of western medicine occurred in 1774 with the publication of the Kaito shinsho, a Japanese translation

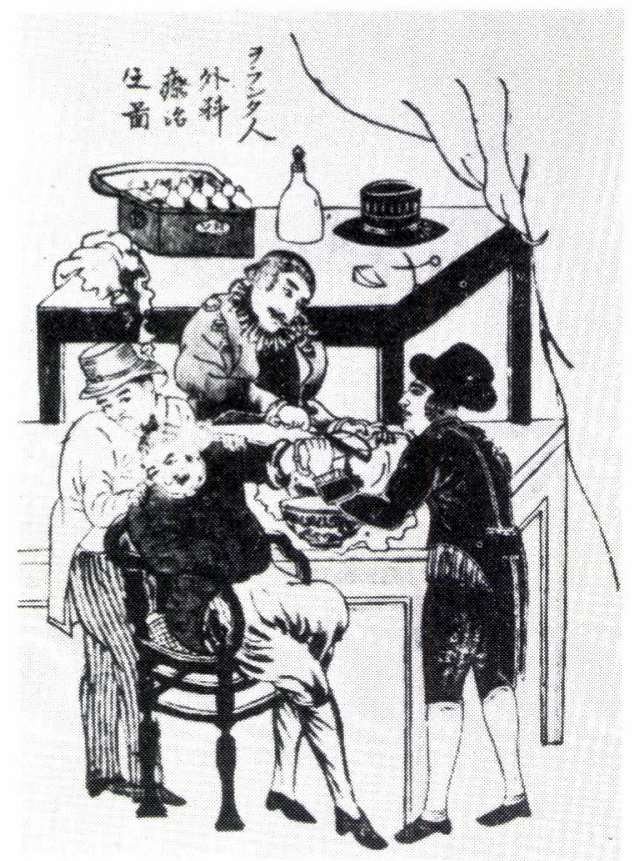

Fig. 3 Amputation of the left forearm performed by a Dutch physician (von Siebold?); a painted woodcut from the second half the $19^{\text {th }}$ cetury.

of a German anatomical text, Tafel Anatomia. This opened the period of "Rangaku"(study of the Dutch language) in which many schools teaching western medicine and Dutch were established in Edo, Osaka, Kyoto, as well as in Nagasaki.

During the period of more than 200 years the Dutch stayed on Deshima, more than 40 VOC-physicians worked in Japan. Although these doctors played a vital role in bringing western knowledge to Japan, they did not succeed to mediate substantially in the other direction. Of course there are several exeptions. E. Kaempfer was a great scholar, botanist, explorer, linguist, and archivist. After scientific explorations in Russia, Persia, Malabar, and Java he reached Japan in 1690. He stayed for two years and recorded voluminous and detailed observations on many aspects of natural history, medicine, and the culture of Japan.

One year after the publication of Kaitai shinsho (1775) another distinguished western physician and botanist C.P. Thunberg, came to Deshima. Thunberg was sent to Japan by a group of wealthy Dutch merchants from Haarlem and Amsterdam who whished to estab- 
lished a major Japanese collection in the Netherlands. Although he stayed at Deshima for only one year Thunberg amassed a truly enormous collection of Japanese specimen and is known as the father of botany in Japan. In 1823, Ph.F.B. von Siebold, an outstanding physician, teacher, and scholar from Germany came to Deshima. In the six years that von Siebold stayed in Japan he taught the Japanese how to perform diagnostic and therapeutic procedures, operative obstetrics, western style cataract operations, and many other surgical interventions (Fig . 3). He attracted medical students and physicians from across Japan and was the first western physician permitted to present organized instruction on the mainland. Seeing von Siebolds exhibits in the museum in Leiden, we can imagine that the collection of the material itself created many problems. For at that time it was prohibited to sell Japanese objects to Europeans and von Siebold had to violate the rules daily to be able to get all the products. On the journey to the court at Edo he was able to make some important purchases including cadastral maps of Japan. Moreover, von Siebold was also active in a more political way and was absolutely convinced that Japan had to change its policy of "sakoku"(isolation). Finally, he was expelled from Japan in 1829 for having secret information of military value. Eleven years after von Siebold's expulsion, in a last-ditch effort under Neo-Confusian pressures the shogunate government banned all Western studies with the exception of medicine. As a result, during the last years of the Edo-period the brightest young minds in Japan enrolled in schools of medicine.

J.L.C. Pompe van Meerdervoort arrived in Japan in 1857, three years after the arrival of the American naval squadron under admiral Perry. The shogunate government recognized the lementable state of the nation's marine defences and sought help from the Hollanders in the establishment of a modern navy. The Japanese also asked the Dutch for assistance in the establishment of a naval military school and for the services of a Dutch medical officer. Pompe van Meerdervoort who had served as an army surgeon in Sumatra and New Guinea received orders to join the naval staff. He was a remarkable medical pioneer who founded the first Western medical school in Japan including a 120-bed teaching hospital.
For five years he was the director of the school and its sole faculty member. He faced many problems in developing the school and the hospital. Some were based on culteral attitudes such as a belief in the inviolability of the human body and bans against dissection. Another was the restriction of his services as a physician to the ruling classes. Thirdly, when he started there was a total lack of teaching aids. He had no textbooks, no charts, and no models. The relations with the government were often made difficult by the continuing hostility to foreigners and the desire of a dying military caste to cling to the seat of power. On the positive side, Pompe enjoyed a talented and dedicated associate in Matsumoto Ryojun. The latter was born in 1804 into a family that had been "okuishi" (physician of the shogun) for generations. He was educated in the "igakkan"(medical hall) of the shogunate were he learned Chinese medicine ("chung-i"). Later Ryojun studied "Rangaku"(Dutch language) and western medicine. He realized that he could not study these sciences to his satisfaction if he remained in Edo and, therefore, he determined to go to Nagasaki to study medicine with the Dutch.

In October 1862 Pompe was succeeded by A.F. Bauduin who immediately took over his duties and started a new medical course. Bauduin introduced many important improvements among which the separation between the instruction in medicine and physics and chemistry. He succeeded in getting the permission of the Japanese government to engage a special teacher for the latter. Consequently, the medical officer W.K. Gratama came to Japan for that purpose in 1856. Particularly the physical and chemical part of the course had great significance for the industrial development of the nation. Bauduin also equipped the hospital with a complete armamentarium chirurgicum and a library.

\section{Conclusion}

In the second half of the seventeenth century Japan had installed a policy of isolation which effectively controlled the flow of information into and from the country. In the exchange of knowledge and in particular of medical sciences the barber-surgeons and later the academically trained physicians of the VOC on one side and the Japanese interpreters and physicians on the other side played an important role. In due course a number of 


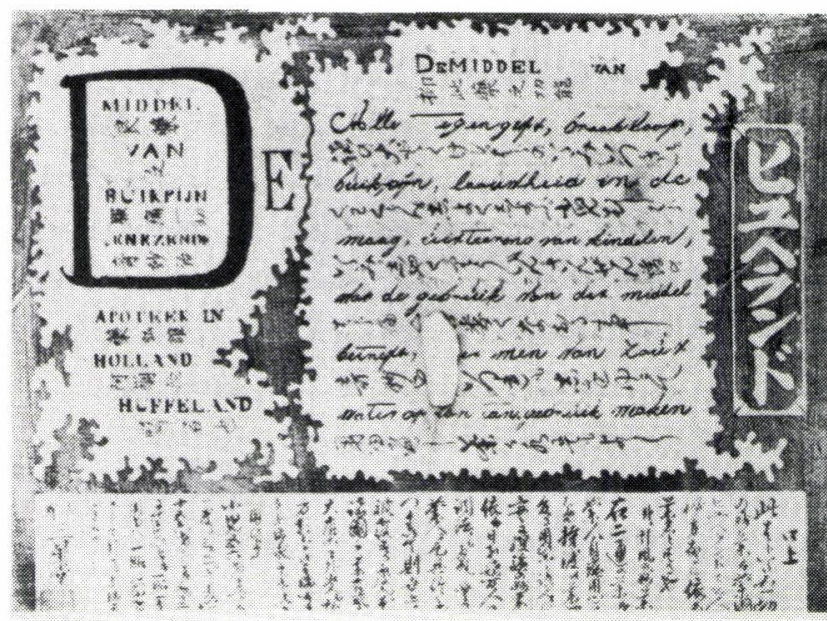

Fig. 4 An advertisement for a therapy of abdominal, cramps, originally written in Dutch by a pharmacist (Huffeland) and later translated into Japanese by an Orandaryn-geka.

the interpreters became physicians of western medicine They helped to translate western books on anatomy, surgery and botany (Fig .4). They also made their private notes on the lessons they followed at Deshima. Some of them set up their own schools of western medicine and new dynasties of medical families. Usually, the VOCdoctors were willing to teach to the best of their abilities and the Japanese were eager to learn. At the end of the Edo-period political ideas changed significantly, in Japan as well as in the Netherlands. For example, the Dutch consul general in Japan prompted a new policy and adopted the firm principle that there should be no longer exceptional circumstances for the Dutch. He preferred to follow the other powers in everything because it was in his opinion clear that, in the long run, Holland would not be able to compete with the big western countries in terms of political influence. Moreover, the Japanese government did realize that likewise. Therefore, Pompe van Meerdervoort, Bauduin and Gratama were members of the last group of European doctors who had brought western medicine to Japan.

\section{References}

1) Wittemans EP, Bowers JZ. Doctor on Desima, selected papers from Jhr J.L.C. Pompe van Meerdervoort's Vijf Jaren in Japan (1857-1863). Sophia University, Tokyo, 1970.

2) Bowers JZ. Western Medical Powers in Feudal Japan. The John Hopkins Press, Baltimore, Maryland, 1970.

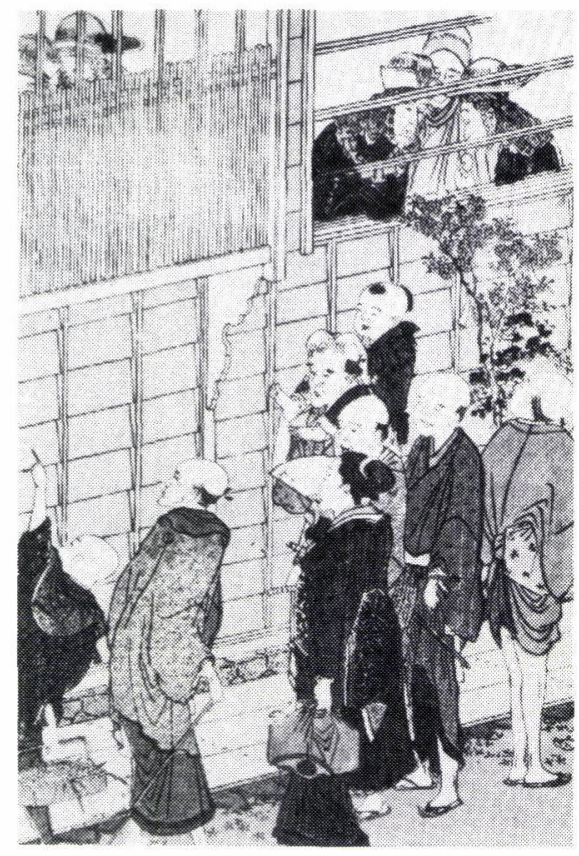

Fig. 5 Inquistive Japanese try to catch a glimpse of Hollanders on their trip to Edo; Hokusai, 1802. It particularly demonstrates so nicely the restrictions which have existed for so many years between the Japanese and Dutch people and it can be also noticed that all the Hollanders on this print have red hair which was one of the preconceptions about Dutchman in Japan.

3) Werger-Klein KE. Barber-surgeons and the transfer of medical and botanical knowledge between Western Europe and Japan in the second half of the seventeenth century. Proceedings of the Oragon Historical Society, North Pacific Studies Center, 1992, accepted for publication.

4) Gratama KW. Leraar onder de Japanners. Brieven van Dr K.W. Gratama betreffende zijn verblijf in Japan (1866-1871). De Bataafsche Leeuw, Amsterdam, 1987.

5) Pompe van Meerdervoort JLC. Dissection of a Japanese Criminal. Journal of the North China Branch, Royal Asiatic Society of Great Britain and Ireland 1860; 2: 85-91.

6) Hesselink RH. Twee spiegels op cambang. Een portret van de Japanners in de negentiende eeuw naar Nederlands ooggetuigenverslagen. Hes Uitgevers, Utrecht, 1984.

7) Stellingwerff J. De diepe wateren van Nagasaki, NederlandsJapanse betrekkingen sedert de stichting van Deshima. Uitgeverij T. Wever b.v., Franeker, 1983.

8) Meech-Pekarik J. The world of the Meiji Print. Impressions of a new civilization. Weatherhill, New York, Tokyo, 1986.

9) Neuer R, Libertson H, Yoshida S. Ukiyo-e, 250 jaar Japanse prentkunst. Atrium, Alphen aan den Rijn, 1991.

10) Huard P, Ohya Z, Wong M. La médicine Japonaise des origines a nos jours. Les Editions Roger Dacorta, Paris, 1974.

11) Paul H. Nederlanders in Japan 1600-1854, De VOC op Desjima. Unieboek bv, Weesp, 1984.

12) Fukuzawa Y. De poorten gaan open. Autobiografie. Meulenhof, Amsterdam, 1978. 